\title{
Japan and identity change: why it matters in International Relations
}

\section{Linus Hagström \& Karl Gustafsson}

To cite this article: Linus Hagström \& Karl Gustafsson (2015) Japan and identity change: why it matters in International Relations, The Pacific Review, 28:1, 1-22, DOI: 10.1080/09512748.2014.969298

To link to this article: http://dx.doi.org/10.1080/09512748.2014.969298 (c) 2014 The Author(s). Published by Taylor \&
Francis.

曲 Published online: 24 Nov 2014.

Submit your article to this journal $\widetilde{ }$

Џll Article views: 3450

Q View related articles ¿

View Crossmark data $\nearrow$ 


\title{
Japan and identity change: why it matters in International Relations
}

\section{Linus Hagström and Karl Gustafsson ${ }^{2}$}

\begin{abstract}
Two approaches to identity have been employed to explore issues in Japan's international relations. One views identity as constituted by domestic norms and culture, and as constitutive of interests, which in turn cause behaviour. Proponents view Japan's 'pacifist' and 'antimilitarist' identity as inherently stable and likely to change only as a result of material factors. In the other approach, 'Japan' emerges and changes through processes of differentiation vis-à-vis 'Others'. Neither 'domestic' nor 'material' factors can exist outside of such identity constructions. We argue that the second, relational, approach is more theoretically sound, but begs three questions. First, how can different identity constructions in relation to numerous Others be synthesised and understood comprehensively? Second, how can continuity and change be handled in the same relational framework? Third, what is the point of analysing identity in relational terms? This article addresses the first two questions by introducing an analytical framework consisting of three mutually interacting layers of identity construction. Based on the articles in this special issue, we argue that identity entrepreneurs and emotions are particularly likely to contribute to change within this model. We address the third question by stressing common ground with the first approach: identity enables and constrains behaviour. In the case of Japan, changes in identity construction highlighted by the articles in this special issue forebode a political agenda centred on strengthening Japan militarily.
\end{abstract}

Keywords emotions; identity change; international relations; Japan; relational identity; norms.

${ }^{1}$ Linus Hagström is Director of the East Asia Programme at the Swedish Institute of International Affairs and Associate Professor of Political Science at the Swedish National Defence College. He is also Research Fellow at the Royal Swedish Academy of Letters, History and Antiquities supported by a grant from the Knut and Alice Wallenberg Foundation. Hagström is the editor of this special issue. He has recently published articles in Chinese Journal of International Politics, Journal of East Asian Studies and European Journal of International Relations.

Address: Linus Hagström Swedish Institute of International Affairs, P.O. Box 27035, 10251 Stockholm, Sweden. Email: linus.hagstrom@ui.se

${ }^{2}$ Karl Gustafsson is a Research Fellow at the Swedish Institute of International Affairs. His research interests include alternative approaches to security and issues related to identity and collective memory in international relations. Empirically, his primary research interest is SinoJapanese relations. He recently published in Asian Perspective and Asian Studies Review.

Address: Karl Gustafsson, Swedish Institute of International Affairs, P.O. Box 27035, 10251 Stockholm, Sweden. Email: karl.gustafsson@ui.se

(c) 2014 The Author(s). Published by Taylor \& Francis.

This is an Open Access article. Non-commercial re-use, distribution, and reproduction in any medium, provided the original work is properly attributed, cited, and is not altered, transformed, or built upon in any way, is permitted. The moral rights of the named author(s) have been asserted. 


\section{Introduction}

The literature on identity and Japan's international relations is dominated by two approaches. 'Norm constructivists' focus on explaining how a domestically constructed 'pacifist' or 'antimilitarist' identity influences foreign policy. The 'relational' approach, in contrast, concentrates on how 'Japan' is constructed vis-à-vis particular 'Others'. It treats identity as reminiscent of a dependent rather than an independent variable, paying less attention to the impact of identity on behaviour or policy. In addition, some scholars have emphasised the resilience of identity, whereas others have stressed its propensity for change. All contributions to this special issue deal with these matters. The main question addressed by all articles is whether and how Japanese identity is changing. Studying identity change is important because when identity constructions change they enable and constrain behaviour in ways that differ from what was previously the case. For example, this special issue highlights that changes in Japan's identity construction foreshadows a political agenda centred on strengthening Japan militarily. Most articles reach this conclusion by focusing on how Japanese identity is constructed in relation to a specific Other. The article written by Andrew Oros, in contrast, represents the norm constructivist position. It is included because it reflects on this position and the overall question of identity change in light of insights from the relational approach.

This introduction integrates the main contributions of the articles into a larger framework. Although we argue that the relational approach is theoretically sounder than norm constructivism, we develop a pragmatic analytical framework that nonetheless can incorporate most of Oros' findings. The article addresses three questions. First, how can different identity constructions in relation to numerous Others be synthesised and understood comprehensively? Second, how can continuity and change be handled in the same relational framework? Third, what is the point of analysing identity in relational terms?

The first section provides a background to research on identity in International Relations (IR) and more particularly Japan's international relations. The second one begins to examine how different findings in the special issue can be synthesised. Combined, the articles suggest that Japanese identity is constructed through the drawing of boundaries vis-à-vis several Others and in multiple contexts. We adopt a layered framework to examine how such identity constructions are maintained and how they transform (Wæver 2002). Based on the contributions to the special issue, section three suggests that two factors play particularly important roles in bringing about identity change: identity entrepreneurs and emotions. The fourth section addresses the question of why and how identities and identity change matter. We argue that the subject positions that emerge through processes of differentiation enable and constrain behaviour, and by extension foreign and security policy. The relational analysis of identity 
can thus be employed for a purpose strikingly similar to the one embraced by norm constructivists. A Japan constructed as 'abnormal' or 'pacifist' is thus believed to act differently from one understood as 'normalising' or 'normal'. Since the discussion draws on a number of case studies, we believe that it offers a firmer basis for making predictions about the future course of Japanese foreign and security policy than each article can do individually.

\section{Japan and identity in its international relations}

With the diffusion of constructivism and post-structuralism in the past few decades, identity has become an explicit and popular focus of IR research. Yet the concept is surrounded by contestation, complaints about its alleged 'vagueness' and 'slipperiness' (Chafetz, Spirtas, and Frankel 1998: vii; Kowert 1998: 4), and even allegations of 'definitional anarchy' (Abdelal, Herrera, Johnston, and McDermott 2006: 695). At the same time, identity shares the predicament of its definition being contested with 'power', 'culture', 'democracy', 'security' and many other concepts in the social sciences (Berenskoetter 2010). Although some scholars see contestation as a reason to discard the concept of identity altogether, in the end they rather tend to adopt different terminology, for instance by talking about 'identification', 'categorisation', 'self-understanding', 'social location', 'commonality', 'connectedness' and 'groupness' (Brubaker and Cooper 2000).

Moreover, assumptions about identity are not confined to recent decades of constructivist and post-structuralist research. For instance, realist scholars tend to view the anarchical international system as moulding security or power-maximising 'territorial states' (Rosecrance 1986). Although this 'status', or identity does not allow for much differentiation between states, the unequal distribution of capabilities still leads to some states being ascribed 'great power' or 'superpower' identities (Mearsheimer 2001; Waltz 1979) while others are known as 'middle powers' or 'small states'.

With its agglomeration of economic capabilities in the post-war period, Japan has commonly been ascribed the identity of an 'economic great power/superpower'. Observers more or less explicitly influenced by realism expected the country to develop commensurate political and military power, and to become a fully fledged 'great power'. However, when Japan failed to do so according to their estimations, the notion spread that the country was an 'anomaly' or 'abnormal' (Kennedy 1994; Layne 1993; Waltz 1993, 2000). The fact that scholars often ascribed Japan other identities than the 'normal' one prompted by realism - for instance, that of a 'trading state' (Rosecrance 1986), a 'civilian' power (Maull 1990/91; Funabashi 1991/92) or a 'reactive' and 'defensive' state (Calder 1988, 2003; Pharr 1993) - demonstrates exactly how central an essentialised and static 'territorial state'/'great power' identity is to realist theory. It also shows 
how deeply embedded that identity is in scholarly, media and policy discourses on Japan's foreign and security policy. Many observers - not all self-proclaimed realists - have continued to represent Japan as an economic 'giant' and a political and military 'pygmy' (Funabashi 1991/92; Inoguchi 1991).

The question of what kind of country Japan is has been pursued in earnest both inside and outside Japan, and not only in the literature on Japan's international relations (Befu 2001; Dale 1986; Littlewood 1996; MorrisSuzuki 1998: 173; Oe 1995: 53; Yoshino 1992). Identity first became the explicit focus of IR research related to Japan in the 1990s. Thomas U. Berger, and Peter J. Katzenstein and Nobuo Okawara tried to resolve the 'abnormality' which they saw at the heart of Japan's foreign and security policy by attributing to it a 'pacifist' or 'antimilitarist' identity. They did so through a focus on what they believed constituted that identity: 'peaceful cultural norms' (Katzenstein 1996a; Katzenstein and Okawara's 1993) and 'antimilitarist culture' (Berger 1993, 1996, 1998; cf. Oros 2008). The most important contribution of these constructivists was to illuminate the often tacit identity component of much IR research on Japan. Their work demonstrated that competing ideas about what Japan is, or is on the verge of becoming, fundamentally boil down to descriptions and predictions of identity. Article 9 of the post-war constitution was key to the identity analysis of these constructivists (Berger 1998; Katzenstein 1996a, 2008). It relinquished Japan's sovereign right to wage wars and to use force or the threat of force 'as means of settling international disputes', and established that 'land, sea, and air forces, as well as other war potential, will never be maintained' (Cabinet Office 1947). The influence of the early 'norm constructivists' on the analysis of Japan's international relations cannot be overestimated. A number of kindred studies have followed in their wake (Ashizawa 2008; Catalinac 2007; Oros 2008; Rozman 2012; Singh 2008).

These norm constructivists argue that identity matters primarily as a determinant of national interest, which they in turn believe to function as a source of foreign and security policy (Finnemore and Sikkink 1998; Hopf 2002; Katzenstein 1996b; Wendt 1999). National interest might seem like an unnecessary intervening variable here, stuck as it is between identity and behaviour. However, its place in the equation has to be understood from the perspective that IR theory has traditionally treated interests as the independent variable and behaviour as the dependent one. While in realism interests are predetermined and essentialised as physical security, liberals are open to the possibility that other interests - such as economic ones (Rosecrance 1986) - can emerge as a result of 'bottom-up' policy processes (Moravcsik 1997: 517). Norm constructivists, in turn, regard interests as socially constructed rather than given, and again consider norms, culture and identities as ideational 'stuff' involved in that social construction.

The debate between realists and these constructivists has often been framed as a struggle between essentially different independent variables - 
structural/material factors for the former and ideational factors in case of the latter. Since even the norm constructivists also continue to attribute explanatory weight to structural/material factors, however, the distinction is not clearcut. Although they believe that norms and culture transform very slowly, and have thus predicted little change in Japan's foreign and security policy (e.g. Berger 1993: 140, 147; 1998: 208; Katzenstein and Okawara 1993: 104, 118), they argue that change will eventually have to come about as a result of changing structural or material conditions (Berger 1993: 120, 1998: 209; Oros 2008: 4, cf. ibid. 172: Friman, Katzenstein, Leheny, and Okawara 2006: 85-87).

By inferring that the international system might 'strike back' against Japanese identity independent of the meaning inter-subjectively ascribed to whatever events are labelled as 'shocks', and by confining the significance of identity to that of an intervening variable, norm constructivism could be criticised for accepting the rationalist terms of debate. It could also be faulted for viewing Japan's 'pacifist or antimilitarist identity' as an inherently and uniquely domestic product, thereby disregarding the notion that a 'domestic domain' is impossible other than in relation to an 'international' one.

Taken together, these points require a rather different concept of identity - a 'relational' understanding where demarcations between domestic and international, identity and difference, or Self and Other are exactly what constitute identity (Campbell 1994, 1998 [1992]; Connolly 1991; Neumann 1996; Rumelili 2004; Wodak, de Cillia, Reisigl, and Liebhart 2009 [1999]). The literature on Japan, which adheres to this concept, has identified a number of Others - both external ones, such as the West, Europe, the US, Asia, China, North Korea and South Korea, and internal ones, such as the outcast group at the bottom of Japan's social order - burakumin, the ainu people (often described as 'indigenous'), Okinawa and the Korean minority in Japan - and it has analysed how these Others have been juxtaposed with Japan to emphasise what Japan is, and hence to construct Japanese identity (Befu 2001; Bukh 2009, 2010; Guillaume 2011; Gustafsson 2011; Hagström 2014; Klien 2002; Morris-Suzuki 1998; Oguma 2002; Schulze 2013; Tamaki 2010; Tanaka 1993).

\section{Analysing identity resilience and change: a layered model}

Berger's and Katzenstein and Okawara's analyses predicted that Japan's identity would remain stable, and it is true that if identity were totally fluid, it would not carry enough meaning to function as an analytical device. Notwithstanding Emanuel Adler's contention that, 'if constructivism is about anything, it is about change' (Adler 2002: 102), much constructivist scholarship resembles research within other IR paradigms in that it focuses more on explaining resilience than change (Finnemore and Sikkink 1998: 888; Kowert and Legro 1996: 488). Instead of stipulating, for ontological 
reasons, that (Japanese) identity is fragile and provisional (Weldes, Laffey, Gusterson, and Duvall 1999: 16), or that it is fixed and stable (Chafetz, Spirtas, and Frankel 1998: $x$ ), the articles in this special issue depart from the ontology that identity's propensity for change is an empirical one (Abdelal, Herrera, Johnston, and McDermott 2006; Brubaker and Cooper 2000).

The question of continuity and change is closely related to the issue of agency vs. structure - a debate on which much ink has been spilled, not least in IR theory (for a revealing exchange see Doty 1997, 2000; Wight 1999, 2000). One way to analyse how change and continuity relate to agency and structure within the same analytical framework is to treat identity as layered, and simultaneously constituted on mutually interacting levels of inter-subjective meaning making. In such a framework, identity change in the less institutionalised layers interacts with and builds on layers that are more institutionalised - whether they too change or not. The latter layers are more 'fundamental' to the extent that they are 'more solidly sedimented and more difficult [for actors] to politicise and change' (Wæver 2002: 31; cf. Laclau and Mouffe 1985: viii). In other words, more sedimented layers of identity construction can enable different identity constructs in less sedimented layers and even sharp turns in identity construction, but changes in the latter can also affect the former (Wæver 2002: 33-42).

We suggest that the most sedimented layer of Japanese identity construction is an understanding of Japan's position in hierarchical terms, where Japan is constructed through its differentiation from Others, who are alternately understood as superior or inferior to Japan (cf. Hagström 2014). As Tamaki's article in this special issue demonstrates, Japanese narratives have tended to portray Asia as inferior to Japan (cf. Tamaki 2010). A critical realist, Tamaki assumes that identity becomes resilient through reification, and he has argued elsewhere that the notion of kokutai ('national polity') embodies a resilient Japanese identity, namely, a 'hierarchic worldview' and an 'associated sense of Japanese "uniqueness", which 'can be identified within the postwar heiwa/shonin kokka [peace/trading state] narratives' (Tamaki 2010: 62). Xavier Guillaume, who subscribes to a relational ontology, agrees that kokutai has been a 'key narrative matrix' in Japanese identity construction (Guillaume 2011: 63-99). Hence, there is agreement that since the second half of the 19th century Japanese identity narratives have positioned Japan between an 'inferior Asia' and a 'superior West'. They have thus reflected desires to catch up with and to be recognised by the West (Suzuki 2005, 2009). As Tamaki's contribution clarifies, these narratives also continue to emphasise Asia's externality to Japan, sometimes as an opportunity that needs to be taken advantage of, but more often in the form of a threat that needs to be handled.

The middle layer is where the more exact distinctions and demarcations between Self and Other are negotiated. At this level, we find multiple 
identities that describe the Others and consequently also the Self. Some identities are more important in certain contexts and in relation to particular Others (Lupovici 2012; Murray 2010: 665). These identities involve concrete self-descriptions, such as 'rational' or 'democratic', as well as corresponding Other-representations such as 'emotional' and 'undemocratic' - the specific traits that are given priority within the hierarchical matrix.

'Othering' is often associated with a negative and dichotomised imagination of difference (Lebow 2008) but this is not necessarily the case (Rumelili 2004). There are various ways of relating to difference, including comparison and integration (Abizadeh 2005; Guillaume 2011). An example is Tamaki's observation that 'Asia' tends to be reified in Japanese narratives as either an opportunity or a threat. In addition, not all of a state's identities need to be constructed in relation to external Others. As Gustafsson's article in this special issue suggests, post-war Japan's 'peaceful' identity has to a large extent been constructed in relation to its own wartime 'aggressive' Self (cf. Abizadeh 2005: 58). At the same time, it is possible that Japan's identity as 'peaceful' might be retained through differentiation from 'less peaceful' external Others (Hagström and Hanssen 2013). Another possibility is the construction of a collective identity with other states (Wæver 2002; cf. Wendt 1999: 336-343). If, for example, the middle layer stresses Japan's identity as a democratic state, this involves emphasis on both the difference from 'undemocratic' states and the similarity with other 'democratic' ones.

The least institutionalised layer is where policies and specific political issues are discussed and where agents operate. The way in which bilateral problems are discussed and understood in this layer is constrained by and has consequences for identity constructions in the other layers, particularly identity constructions in relation to specific others in the middle layer. If the behaviour of several Others is similarly interpreted in relation to a number of issues, it may affect multiple middle-layer identities. For example, if Japan's Others are depicted as behaving as 'bullies', it is likely that the Self's identity as a victim will be strengthened in the middle layer, as is illustrated in several contributions to this special issue and discussed in greater detail below.

\section{Factors contributing to identity change}

As is noted above, based on the contributions to this special issue, two factors have been identified that arguably play important roles in effectuating identity change within the layered model: identity entrepreneurs and emotions.

\section{Identity entrepreneurs and identity change}

The notion that research should trace the process whereby identity is constructed means that it should account for the contestation involved, or the 
politics of identity (Neumann 1996: 165; Abdelal, Herrera, Johnston, and McDermott 2006: 696; Guillaume 2011). Actors seem to realise that much is at stake in identity politics. As Oros discusses in his article in this special issue, conservative Japanese political actors have attempted to change Japan's security identity throughout the post-war period. Bukh also emphasises the role of contestation as he shows that regional actors from Shimane prefecture, in defiance of central national elites, have played an important role in promoting the Takeshima issue and in contributing to identity change. Other research shows that conservative Japanese actively try to influence not only Japanese but also Chinese identity (Gustafsson 2014).

Like 'norm entrepreneurs', identity entrepreneurs call attention to, or even create, issues 'by using language that names, interprets, and dramatizes them', thereby promoting the identities that they themselves espouse (Finnemore and Sikkink 1998: 897; see also Keck and Sikkink 1998). In other words, as Bukh, Gustafsson, Hagström and Hanssen, and Suzuki all show, identity entrepreneurs are political actors who promote their desired versions of Japanese identity through the discursive representation of issues and actors. These entrepreneurs operate most obviously at the least sedimented layer where agency is less constrained by structure. Their representations are likely to influence identity constructions in relation to Others in the middle layer. In addition, identity entrepreneurs do not merely reproduce but also seek to alter identities. Oros is also concerned with the agency exercised by actors, who at the same time promote different identity conceptions and security policies, but his focus is on 'domestic institutions and electoral politics'.

While some observers argue that identities can be manipulated (Kowert and Legro 1996: 493), others question the extent to which it is possible for actors to be autonomous of identity narratives (Campbell 1998 [1992]: 218; Suzuki 2007: 27). The latter view implies that there is a limit to how far identity discourses can be 'actorised', and that identity entrepreneurs are not cynical, rational actors who tamper with identities in an instrumentalist and strategic way in order to achieve their purposes without themselves being under the influence of identities (cf. Wodak, de Cillia, Reisigl, and Liebhart 2009 [1999]: 31-32).

This point could be rephrased by saying that two kinds of power are at work in the construction of identities. Discursive, narrative or productive power works to produce and maintain identity constructions, or to transform them when discourses are pitted against each other (Barnett and Duvall 2005; Digeser 1992). At the same time, a relational understanding of power suggests that actors at times play a privileged role in the formation, maintenance and transformation of identities (on 'relational power' see Baldwin 2013 [2002]; Hagström 2005).

The issues discussed in the articles are all closely linked to particular Others: South Korea for Bukh, North Korea for Hagström and Hanssen, 
and China for Gustafsson and Suzuki. The concrete issues analysed all emerged with force in the mid-2000s, in some cases after having been long dormant, and this might lead to more substantial changes in Japanese identity construction in the middle layer. These issues have provided a window of opportunity for identity entrepreneurs to discredit Japan's 'pacifist' or 'peaceful' post-war identity as 'mistaken', 'abnormal' and 'weak'. They seem to regard it as excessively or naively peaceful, because it enables other states to 'bully' Japan. The negative adjectives associated with Japan's Others, in contrast, include 'arrogant', 'aggressive', 'undemocratic', 'immoral', 'irrational', 'unreasonable', 'nationalistic', 'disrespectful of international law' and 'emotional', suggesting that unlike them Japan could remain peaceful, albeit not excessively so (cf. Hagström 2012).

Hagström and Hanssen, as well as Suzuki, suggest that the tables have recently been turned in Japanese discourses on Japan-North Korea relations and Sino-Japanese relations. The previously dominant discourses on North Korea and China as 'victims' of Japanese aggression during the war have largely been replaced by discourses in which North Korea and China are constructed as 'aggressors' or 'bullies' that make 'unreasonable demands', and Japan is portrayed as the 'victim'. Similarly, in discussions of Chinese 'anti-Japanism' outlined in Gustafsson's article, the customary understanding of what the 'history problem' in Sino-Japanese relations consists of is increasingly challenged as China is seen to be denying Japan's peaceful identity. This identity change from 'aggressor' to 'victim' exemplifies how the work of identity entrepreneurs at the least sedimented layer has consequences for identity construction in the middle layer.

\section{Emotions and identity change}

Even though often discussed in classical texts, IR theory during the Cold War largely ignored the role of emotions. It did so because it viewed states as rational actors making decisions based on given national interests within boundaries set by material structures. In realism, only one emotion is regarded as legitimate and rational: fear (Crawford 2000; Hall 2006; Weber 2010: 14-36). Moreover, rational fear was equated with physical threats and the pursuit of physical security (Saurette 2006: 495-496). With the exception of research on misperceptions in foreign policy decision-making, emotions remained largely neglected in IR until the late 1990s. However, fear linked to issues traditionally not associated with 'hard' threats to physical security, along with other emotions such as shame, anxiety, sympathy, anger and feelings of insult, could play an important role in identity change in all three layers of our model.

Mainstream approaches have thus tended to portray emotions as irrational. However, it has been convincingly argued that the distinction between rationality and emotion is untenable. Rational action requires emotion 
since actors have to empathise to make rational decisions (Mercer 2010). Moreover, as Bleiker and Hutchison (2008: 123) argue, '[e]motions help us make sense of ourselves, and situate us in relation to others and the world that surrounds us'. Identity is thus constructed through the forging of an emotional allegiance that makes us feel like we belong. As Jan Assmann observes, '[c]ollective identity is a matter of identification on the part of the participating individuals. It does not exist "in itself", but only ever to the extent that specific individuals subscribe to it. It is as strong - or as weak - as it is alive in the thoughts and actions of the group members, and able to motivate their thoughts and actions' (Assmann cited in Heer and Wodak 2008: 7). When one identifies with a particular notion, one feels part of a certain collective. It follows that without emotional attachment, identities are difficult to construct. In such a situation, identity entrepreneurs appear more seldom and are much less likely to succeed.

The link between emotion and identity is particularly clear in discussions of nationalism and patriotism (cf. Mercer 2010). Some scholars argue that nationalism involves 'malign' feelings of superiority, which may lead to hatred of the Other, whereas patriotism is 'benign' or 'healthy' and associated with love for one's own nation (Gries, Zhang, Crowson, and Cai 2011; Kosterman and Feshbach 1989). Others argue that a strong love for and pride in one's country is not necessarily benign as it is a more basic motivation for self-sacrifice than hatred of the Other, and therefore a more fundamental reason for people's willingness to go to war (cf. Anderson 1983: 7; Billig 1995: 55-59). In addition, love or pride in one's own country implies comparison, and it therefore often involves feelings of disdain in relation to the Other. Either way, it is clear that emotions form the basis of both patriotic and nationalistic identities. This is especially clear in the Japanese language, where a literal translation of the word for patriotism is lovecountry-feeling (aikokushin).

At the same time, the Self is often represented as rational and unemotional, whereas the Other is depicted as excessively emotional in its expression of national identity (Billig 1995: 43-46, 55-59; Mercer 2010: 21). For example, as the articles in this special issue highlight, Japanese discourses portray both China and South Korea as emotional in contrast to Japan. Yet emotions paradoxically play a key role in the strategies of Japanese identity entrepreneurs. For example, Hagström and Hanssen shed light on how emotional traumas related to the North Korean abduction issue are involved in attempts to effectuate identity change. They do not understand trauma as an external 'shock', but as the specific emotional interpretation of an event. Hagström and Hanssen emphasise that the diffusion of emotions of sympathy and anger within Japan contributed to the collectivisation and politicisation of the abduction issue in a way that makes Japanese identity change possible.

Gustafsson's analysis suggests that the perceived Chinese denial of recognition of Japan's peaceful identity produces feelings of shame and insult, 
also contributing to identity change. Some approaches to ontological security argue that actors feel shame when there is dissonance between their actions and their self-identity (Steele 2008). When faced with denials of recognition, moreover, actors can either accept how they are described and experience shame, or refuse to accept the description and instead feel insulted, much like the Japanese actors in Gustafsson's account (cf. Ringmar 1996, 2012). Both shame and feelings of insult are emotions closely linked to an agent's sense of Self, and as such they function as drivers of identity change.

Japanese discussions of Japan as 'weak' and 'inferior', in Suzuki's analysis, could also be interpreted in terms of shame. In an international society that values 'great powerness' or 'superpowerness', weakness is typically understood as embarrassing or even shameful. As Suzuki points out, Japanese politicians are criticised for 'making Japan look weak' vis-à-vis China. Since their behaviour is understood as embarrassing or shameful, they are urged to act more decisively.

Bukh's analysis also suggests that identity change can be generated by ontological insecurity or anxiety about one's sense of Self. In a similar way to Tamaki's treatment of Japanese discourses on Asia, Bukh argues that Japanese identity has consistently been constructed in relation to a notion of South Korea as inferior. Until recently, Japan's ontological security at the most sedimented layer of the model was confirmed by the inferior economic status of South Korea. However, South Korea's economic development has arguably made the country increasingly like Japan. This has made it difficult to maintain a Japanese sense of uniqueness or superiority in relation to South Korea in this dimension. This is not a threat to Japan's physical security or survival, but a threat to its ontological security. A similar argument might be made in relation to China, which surpassed Japan as the world's second largest economy in 2010 (Schulze 2013).

Bukh argues that this anxiety has been handled by emphasising that South Korea is 'emotional', 'nationalistic' and 'lacking respect for international law' in its behaviour towards the Takeshima/Dokdo dispute and related issues such as education. In this way, the fundamental hierarchical matrix has been stabilised through an adjustment in the middle layer of the framework. Hence, Japan is still depicted as superior, albeit not in the area of economics but in its 'disposition' or 'national character'. In contrast to South Korea, Japan is described as more 'mature', 'rational' and 'law-abiding'.

Suzuki's and Gustafsson's analyses similarly highlight how Japan is differentiated from China. Now that Japan is no longer economically superior to China in terms of GDP, it is depicted as superior in other spheres. Chinese denial of Japan's 'peaceful' identity, and its 'arrogant', 'bullying' and 'overbearing' behaviour in bilateral disputes, is therefore stressed, and China is portrayed as 'undemocratic', 'irrational', 'unreasonable', 'immoral', 'anti-Japanese' and 'lacking respect for international law'. This suggests that Japan, in contrast, is 'democratic', 'reasonable', 'moral' and 'law-abiding'. 
On the basis of this discussion, norm constructivists, such as Oros in this special issue, might conclude that material factors cause identity change. After all, it might be argued that the economic development of China and South Korea threatens Japan's ontological security. We suggest, however, that this is a spurious conclusion. First, agents may attempt to substantiate their socially constructed identities in material practices and capabilities, thereby making them appear as brute facts (Murray 2010: 663-667). In addition, it is only because Japan's identity (or one of its identities) was that of an 'economic power', and hence constructed on the basis of material factors, that China and South Korea's economic development has produced anxiety in Japan. Japan's other identities, for example that of a 'peaceful state', were not threatened by the economic development of South Korea and China. We do not contest the existence of structural and material factors, or of a reality external to thought, but we do contest the possibility that these factors can have any precise or clear meaning independent of the discourses in which they are constituted as objects (cf. Laclau and Mouffe 1985: 108). For example, a forest can be viewed as an obstacle to the construction of a highway, a source of material when building wooden houses or a scenic area in need of protection from the former. Similarly, the 'rise of China' can be interpreted as an opportunity, as a threat, or in other ways.

\section{Why and how identity (change) matters in International Relations}

As is discussed above, post-war Japan was ascribed the identities of an 'economic great power/superpower/giant' and a 'military dwarf', and those of a 'passive', 'reactive' and overall 'abnormal' state because its foreign and security policy was interpreted as deviating from the inter-subjectively defined international standard. Hence, there is a tacit connection between the identities that are more or less habitually ascribed to states, such as Japan, and their policies or behaviour. When norm constructivists, such as Katzenstein and Berger, introduced the concept of identity into the literature on Japan's international relations in the 1990s, they did so explicitly to explain policies or behaviour. These constructivists held that identities constitute national interests, which in turn shape or regulate behaviour (Finnemore and Sikkink 1998; Hopf 2002; Katzenstein 1996b; Wendt 1999).

When constructivism and post-structuralism adopted a relational view on identity, by contrast, there was a tendency to analyse identity more for its own sake, to make sense of the formation, maintenance and transformation of collective identities such as 'state' and 'nation', and by extension to understand the production and reproduction of the 'interstate' and the 'international' (Williams 1998). Hence, such research treated identity as reminiscent of a dependent variable, and the social construction of identity was analysed mostly through variations of discourse analysis (cf. Phillips and Hardy 2002: 2). 
Described as such, relational identity analysis appears incommensurable with the norm constructivist analysis of identity presented above. However, although few relational analyses of identity elaborate in detail on the analytical role of identity - beyond stipulating the intrinsic value of elucidating and problematising the construction of 'imagined communities' some works do argue that there is a connection between discursively constructed social identities, 'interpretative dispositions' and propensities for action (Doty 1993: 298).

The question is thus not only how identities emerge as a product of narratives and discourses but also how emergent subjects 'live out their identities and act' (Howarth and Stavrakakis 2000: 12). The question could be rephrased by interrogating what behaviour or policy discursively produced identities enable or constrain, by either promoting or excluding certain possibilities (Phillips and Hardy 2002: 21) - that is, by delineating the 'range of imaginable conduct' (Doty 1993: 299). Hutchison argues that traumas play an important role in destabilising identities and making possible their reconfiguration in ways that facilitate hawkish security policies (Hutchison 2010: 66-68, 81-83).

The recognition or denial of recognition that Others bestow on the Self's construction of identity also influences its propensities for action (Ringmar 2012). Erik Ringmar puts it succinctly: 'It is only as some-one that we can want some-thing, and it is only once we know who we are that we can know what we want' (Ringmar 1996: 13, italics in original). Identity, then, is fundamentally about agency. If we do not know who we are we will not know what to do. Since the 'range of imaginable conduct' is defined, inter alia, through the production and reproduction of discursively emergent norms and institutions, there is again notable common ground with norm constructivism.

While Michel Foucault sought to analyse how discourses on 'madness' and 'punishment' affected medical, psychiatric and legal practices and institutions, and Edward Said aimed to demonstrate how statements about 'the Orient' provided the 'means for the appropriation of the Orient by successive waves of European colonialization and imperialism' (Howarth 2000: 68), several articles in this special issue address the question of how discourses on Asia, China and the two Koreas affect the practices and institutions of Japanese foreign and security policy, and produce the range of possible Japanese conduct vis-à-vis its neighbouring countries.

Hence, even if one acknowledges that states are constructions of the imagination that come into being through the collective meaning-making of human beings, for example, through 'foreign and security policy', on another level it seems perfectly reasonable to ask what consequences such identity constructions might have for foreign and security policy. Although we define identity differently from norm constructivists, we agree that action can be understood from the viewpoint of identity. However, while the mapping of a certain discourse 'does not explain specific 
decision-making processes' (Neumann 2003: 48 emphasis added) or provide unambiguous 'templates for action' (Jackson 2004: 286), it can illuminate the overall past policy direction. Most importantly, perhaps, it can be used to make negative predictions (Wæver 2002: 32) - to suggest policies that are unlikely to be implemented in the foreseeable future. A sufficient number of negative predictions, moreover, implies a set of possibilities or positive predictions.

The discourse/identity literature rarely theorises the connection between discursively constructed identity and propensities for action further than this. Jack Holland, however, has criticised some of this literature for conflating 'imaginability', 'conceivability' and 'thinkability', on the one hand, and 'possibility', on the other. He argues that a course of action becomes possible not only by being conceivable, but that 'communicability' and 'coerciveness' are also necessary. He thus advises analysts of political possibility to address 'how thinkable', 'how resonant' and 'how dominant' a particular action is (Holland 2013: 52). We agree that communicability and coerciveness are crucial, but believe they are already inherent in the notion of conceivability - or at least that they should be. Something only becomes collectively conceivable if it is at the same time communicable and coercive. Perhaps Holland conflates conceivability with 'utterance', as when he states that '[p]olitical possibility is not achieved in the utterance alone (ibid. p. 53). However, crucially, collective inconceivability does not mean that something is individually inconceivable. It merely means that it will not be supported or accepted by the collective. Oros' article illuminates this issue as he shows how the Japanese identity entrepreneurs attempting to refashion Japan's security identity have long found themselves constrained by the strength of domestic antimilitarism.

With the exception of Bukh, all articles included in this special issue endeavour to make analytical connections between identity and propensity for action - both policy developments in the past and present, and possible future directions. Suzuki argues that the increasingly similar construction of a 'bullying Chinese Other' on the political right and left could have the consequence that 'Japanese politicians come under increased criticism for following this relatively moderate "established" policy towards China' and that 'Tokyo will be less afraid of "straining" Sino-Japanese relations further'. He warns that 'if China continues to be "Othered" as a high-handed, arrogant neighbour, we could be set to witness many more diplomatic standoffs between these two great powers of East Asia for some years to come'.

Tamaki, moreover, argues not only that a resilient notion of Asian Otherness continues to define the range of conceivable conduct in Japan, but also that widespread narratives of Asia in terms of 'threat' or 'danger' currently set much narrower confines than previously. These dangers, which are associated with North Korea, China and Russia, have for example made it possible or even seem necessary to strengthen Japan's military capabilities, reorganise command structures and increase the Japanese 
defence budget. As Tamaki notes, it is also within this context that debates over collective self-defence - a reinterpretation or a possible revision of Article 9 of the constitution - have been 'revisited'.

The developments and possible future trajectories that Tamaki highlights are often known as Japan's 'normalisation' or 'remilitarisation'. Gustafsson, and Hagström and Hanssen present different arguments as to why this might indeed be the direction in which Japanese foreign and security policy is headed. Gustafsson argues that China's non-recognition of Japan's allegedly 'peaceful' identity in the post-war period presents an opportunity for Japanese conservatives to argue that the 'peaceful' identity should be exchanged for the identity of a 'normal' state, which in turn enables a revision of Article 9 and the strengthening of the Japanese military. Hagström and Hanssen, furthermore, contend that the abduction issue can be understood as a 'vehicle for renegotiating Japanese identity'. Through the diffusion of emotions - particularly through the discursive construction of Japan as 'victim' and North Korea as 'aggressor' - the issue has been securitised and collectivised so that 'normalisation'/'remilitarisation' has become politically possible.

As Oros describes in his article, throughout the post-war period conservative lawmakers in the Liberal Democratic Party (LDP) have pursued a political agenda centred on Japan's 'normalisation' as a nation state and revision of the constitution. Indeed, the aims of amending Article 9 and remilitarising Japan were allegedly a driving factor behind the LDP's establishment in 1955 (Hagström 2010: 513). Some observers interpreted this agenda as a step towards Japan's remilitarisation already in the 1980s (Hook 1988, 1996), but it is arguably more accurate to characterise the post-war era as a constant tug of war between concomitant forces working towards remilitarisation and demilitarisation. Hence, the pacifist policies of the Japan Socialist Party (JSP) were distinct from the policies of the LDP in that they opposed both the security treaty with the United States and the establishment of Japan's Self-Defense Forces. The JSP, moreover, was strong enough to provide a viable political alternative to the LDP. This has even been taken as evidence that two opposing identities were at work in post-war Japan - one 'pacifist' (heiwa shugi) and one 'traditional statist' (dentoteki kokka shugi) (Soeya 2005). The fact that the political left has become politically weak might also suggest that the 'pacifist' identity has weakened. Most of the current opposition parties support variations of the agenda to alter Article 9.

Having previously been collectively inconceivable, we therefore argue that revision of Article 9 and remilitarisation have come to appear politically possible in large part because this agenda has become more resonant and ubiquitous. As Hagström and Hanssen show, its dominance has been achieved through verbal and physical sanctions - in their case against dissenters in the abduction issue debate. Oros, moreover, points out that it has become less costly in terms of political capital to adopt policies 
contrary to the hitherto dominant security identity, which he sees as one of anti-militarism. Nonetheless, to argue that revision of Article 9 and remilitarisation have entered the realm of the politically possible is not the same as stating with any degree of certainty how likely it is that such policy changes will take place - or when they might happen. As Oros writes, although the current Prime Minister, Abe Shinzō, and many other conservative politicians do not subscribe to the 'core tenets of anti-militarism', they remain highly constrained by them.

\section{Conclusions}

This article argues that a relational concept of identity is theoretically more sound than the identity concept espoused by the norm constructivists, who nonetheless have to be lauded for their instrumental role in explicitly introducing identity into the study of Japan's international relations. Fundamentally, we argue that the notion of 'domestically produced identities' is problematic, because it reifies the very boundaries between inside and outside that investigations into identity should seek to understand and problematise. Moreover, although the norm constructivists predicted little change in Japan's foreign and security policy, they believed that change would eventually have to occur as a result of an outside shock defined in material terms. While we agree that material factors may play some role, we argue that this role is indeterminate and that the meaning ascribed to material conditions does not necessarily follow from 'brute facts'. One example is the notion that post-war Japan was a 'military dwarf', which has been reproduced in many contexts despite the fact that Japan at the same time had one of the largest defence budgets in the world, and also one of the world's most technologically advanced defence forces (Hagström 2005). Hence, we argue that the meaning of these 'material factors' is discursively constructed.

In line with their different ontologies, some relational accounts of identity emphasise the possibility of identity being resilient, while others are more inclined to stress fragility and fluidity. In this article, in contrast, we adopt an ontology on the basis of which both are possible and where the question can only be illuminated through empirical enquiry. More specifically, an analytical model consisting of three mutually interacting layers, in which identities are institutionalised to different degrees, allows us to account for both continuity and change. Equipped with this model, we are able to synthesise the findings of this special issue in a more comprehensive assessment. Based on the contributions, we argue that identity entrepreneurs and emotions play important roles in effectuating identity change within the layered model. Entrepreneurs have some agency but are also constrained by more institutionalised layers. Emotions, moreover, are produced and reproduced in all three layers, and thus comprise aspects of 
both agency and structure. Finally, we argue that identity understood in relational terms shares one important analytical application with the identity concept developed by norm constructivists in that it is seen to enable and constrain behaviour or policy.

Based on the individual contributions, we conclude that at the most sedimented layer, Japan remains constructed as 'superior'. It is mainly at the middle layer that a more general Japanese identity shift is taking place from that of an 'economic giant' to that of a mature, moral and law-abiding country, which is threatened and even victimised by morally inferior neighbours. Moreover, all the contributions, in one way or another, relate to Japan's 'pacifist' or 'antimilitarist' identity. Suzuki suggests that some identity entrepreneurs regard this identity as a reason for Japanese weakness, which makes it possible for China to 'bully' Japan. Similarly, Tamaki proposes that 'Asia' is increasingly understood as a threat, which necessitates Japan's 'normalisation' as a nation state. Gustafsson, furthermore, argues that the 'peaceful' identity becomes easier to change in such a direction due to the Chinese denials of it. Hagström and Hanssen's analysis reveals how North Korean abductions are interpreted as a trauma that could have been avoided had Japan not been excessively and 'abnormally' 'peaceful'. Japan's 'pacifist' identity in the post-war period is thus depicted as a threat to Japan's 'true' identity and physical survival. Hence, this identity is now more easily portrayed as mistaken and 'abnormal', and it might therefore have to be abandoned or at least altered to make it possible for Japan to deal with its difficult Others. Oros agrees that Japan's post-war identity is 'under siege', but also persuasively demonstrates how a security identity of domestic antimilitarism continues to constrain the sometimes ambitious political agendas of political actors, such as that of Prime Minister Abe Shinzō. Nonetheless, despite the continuing constraining power of this identity, it has probably never been more thoroughly challenged than it currently is.

\section{Acknowledgements}

For insightful comments on earlier drafts of this article we would like to thank Stefan Borg, Alexander Bukh, Björn Jerdén, Andrew Oros and one anonymous reviewer.

\section{References}

Abdelal, R., Herrera, Y. M., Johnston, A. I. and McDermott R. (2006) 'Identity as a variable', Perspectives on Politics 4(4): 695-711.

Abizadeh, A. (2005) 'Does collective identity presuppose an other? On the alleged incoherence of global solidarity', American Political Science Review 99(1): 45-60. 
Adler, E. (2002) 'Constructivism and international relations', in W. Carlsnaes, T. Risse and B. Simmons (eds) Handbook of International Relations, New Delhi: SAGE, pp. 95-118.

Anderson, B. (1983) Imagined Communities: Reflections on the Origin and Spread of Nationalism, London: Verso.

Ashizawa, K. (2008) 'When identity matters: state identity, regional institutionbuilding, and Japanese foreign policy', International Studies Review 10(3): 571-98.

Baldwin, D. A. (2013) [2002] 'Power and international relations', in W. Carlsnaes, T. Risse and B. Simmons (eds) Handbook of International Relations, New Delhi: SAGE, pp. 273-97.

Barnett, M. and Duvall, R. (2005) 'Power in international politics', International Organization 59(1): 39-75.

Befu, H. (2001) Hegemony of Homogeneity: An Anthropological Analysis of Nihonjinron, Melbourne: Trans Pacific Press.

Berenskoetter, F. (2010) 'Identity in international relations', in R. Denemark (ed) The International Studies Encyclopaedia, Oxford: Wiley-Blackwell.

Berger, T. U. (1993) 'From sword to chrysanthemum: Japan's culture of anti-militarism', International Security 17(4): 119-50.

Berger, T. U. (1996) 'Norms, identity, and national security in Germany and Japan', in P.J. Katzenstein (ed) The Culture of National Security: Norms and Identities in World Politics, New York: Columbia University Press, pp. 317-56.

Berger, T. U. (1998) Cultures of Antimilitarism: National Security in Germany and Japan, Baltimore: Johns Hopkins University Press.

Billig, M. (1995) Banal Nationalism, London: SAGE.

Bleiker, R. and Hutchison, E. (2008) 'Fear no more: emotions and world politics', Review of International Studies 34(1): 115-35.

Brubaker, R. and Cooper, F. (2000) 'Beyond "identity", Theory and Society 29(1): $1-47$.

Bukh, A. (2009) 'Identity, foreign policy and the "Other": Japan's "Russia", European Journal of International Relations 15(2): 319-45.

Bukh, A. (2010) Japan's National Identity and Foreign Policy: Russia as Japan's 'Other', London: Routledge.

Cabinet Office (1947) The Constitution of Japan, accessed at http://www.kantei.go. jp/foreign/constitution_and_government/frame_01.html, 30 October 2014.

Calder, K. (1988) 'Japanese foreign economic policy formation: explaining the reactive state', World Politics 40(4): 517-41.

Calder, K. (2003) 'Japan as a post-reactive state?', Orbis 47(4): 605-16.

Campbell, D. (1994) 'Policy and identity: Japanese Other/American Self', in N. Inayatullah, S. J. Rosow and M. Rupert (eds) The Global Economy as Political Space: A Crucial Reader in International Political Economy, Boulder: Lynne Rienner, pp. 147-69.

Campbell, D. (1998) [1992] Writing Security: United States Foreign Policy and the Politics of Identity, Manchester: Manchester University Press.

Catalinac, A. L. (2007) 'Identity theory and foreign policy: explaining Japan's responses to the 1991 Gulf War and the 2003 US War in Iraq', Politics \& Policy 35(1): 58-100.

Chafetz, G., Spirtas, M. and Frankel, B. (1998) 'Introduction: tracing the influence of identity on foreign policy', Security Studies 8(2-3): 7-22.

Connolly, W. E. (1991) Identity/Difference: Democratic Negotiations of Political Paradox, Minneapolis: University of Minnesota Press.

Crawford, N. C. (2000) 'The passion of world politics: propositions on emotion and emotional relationships', International Security 24(4): 116-56. 
Dale, P. N. (1986) The Myth of Japanese Uniqueness, London: Routledge.

Digeser, P. (1992) 'Fourth face of power', Journal of Politics 54(4): 977-1007.

Doty, R. L. (1993) 'Foreign policy as social construction: a post-positivist analysis of US counterinsurgency in the Philippines', International Studies Quarterly 37 (3): 297-320.

Doty, R. L. (1997) 'Aporia: a critical exploration of the agent-structure problematique in International Relations theory', European Journal of International Relations 3(3): 365-92.

Doty, R. L. (2000) 'A reply to Colin Wight', European Journal of International Relations 5(3): 387-90.

Finnemore, M. and Sikkink, K. (1998) 'International norm dynamics and political change', International Organization 52(4): 887-917.

Friman, R. H., Katzenstein, P. J., Leheny, D. and Okawara, N. (2006) 'Immovable object? Japan's security policy in East Asia', in P. J. Katzenstein and T. Shiraishi (eds) Beyond Japan: The Dynamics of East Asian Regionalism, Ithaca: Cornell University Press, pp. 85-107.

Funabashi, Y. (1991/92) 'Japan and the new world order', Foreign Affairs 70(5): $58-74$.

Gries, P. H., Zhang, Q, Crowson, H. M. and Cai, H. (2011) 'Patriotism, nationalism and China's US policy: structures and consequences of Chinese national identity', The China Quarterly 205: 1-17.

Guillaume, X. (2011) International Relations and Identity: A Dialogical Approach, London: Routledge.

Gustafsson, K. (2011) Narratives and Bilateral Relations: Rethinking the History Issue in Sino-Japanese Relations, Ph.D. dissertation (Stockholm Studies in Politics 139), Stockholm: Stockholm University.

Gustafsson, K. (2014) 'Memory politics and ontological security in Sino-Japanese relations', Asian Studies Review 38(1): 71-86.

Hagström, L. (2005) 'Relational power for foreign policy analysis: issues in Japan's China Policy', European Journal of International Relations 11(3): 395-430.

Hagström, L. (2010) 'The democratic party of Japan's security policy and Japanese politics of constitutional revision: a cloud over Article 9? Australian Journal of International Affairs 64(5): 510-25.

Hagström, L. (2012) " "Power shift" in East Asia? A critical reappraisal of narratives on the Diaoyu/Senkaku Islands incident in 2010', The Chinese Journal of International Politics 5(3): 267-97.

Hagström, L. and Hanssen, U. (2013) 'What "peace” enables: from 'normalisation' of Sino-Japanese relations to the 'normalisation' of Japanese foreign and security policy?', Paper Presented at the Workshop 'The Rise and Demise of Asian World Supremacy: Power, Effects and Identities', Swedish Institute of International Affairs, Stockholm; 28-29 August.

Hagström, L. (2014) 'The "abnormal" state: identity, norm/exception and Japan', European Journal of International Relations. doi:10.1177/1354066113518356.

Hall, M. (2006) 'The fantasy of realism, or mythology as methodology', in D. H. Nexon and I. B. Neumann (eds) Harry Potter and International Relations, Lanham, MD: Rowman \& Littlefield, pp. 177-93.

Heer, H. and Wodak, R. (2008) 'Introduction: collective memory, national narratives and the politics of the past, the discursive construction of history', in $\mathrm{H}$. Heer, W. Manoschek, A. Pollak and R. Wodak (eds) The Discursive Construction of History: Remembering the Wehrmacht's War of Annihilation, Basingstoke: Palgrave Macmillan, pp. 1-16.

Holland, J. (2013) 'Foreign policy and political possibility', European Journal of International Relations 19(1): 49-68. 
Hook, G. D. (1988) 'The erosion of anti-militaristic principles in contemporary Japan', Journal of Peace Research 25(4): 381-94.

Hook, G. D. (1996) Militarization and Demilitarization in Contemporary Japan, London: Routledge.

Hopf, T. (2002) Social Construction of International Politics: Identities \& Foreign Policies, Moscow, 1955 \& 1999, Ithaca: Cornell University Press.

Howarth, D. (2000) Discourse. Buckingham and Philadelphia: Open University Press.

Howarth, D. and Stavrakakis, Y. (2000) 'Introducing discourse theory and political analysis', in D. Howarth, A. J. Norval and Y. Stavrakakis (eds) Discourse Theory and Political Analysis: Identities, Hegemonies and Social Change, Manchester: Manchester University Press, pp. 1-23.

Hutchison, E. (2010) 'Trauma and the politics of emotions: constituting identity, security and community after the Bali bombing', International Relations 24 (1): $65-86$.

Inoguchi, T. (1991) Japan's International Relations, Oxford and San Francisco: Westview Press.

Jackson, P. T. (2004) 'Hegel's House, or "People are states too"', Review of International Studies 30(2): 281-7.

Katzenstein, P. J. (1996a) Cultural Norms and National Security: Police and Military in Postwar Japan, Ithaca: Cornell University Press.

Katzenstein, P. J. (1996b) 'Introduction: Alternative perspectives on national security', in P. J. Katzenstein (ed) The Culture of National Security: Norms and Identities in World Politics, New York: Columbia University Press, pp. $1-32$.

Katzenstein, P. J. (2008) Rethinking Japanese Security: Internal and External Dimensions, London: Routledge.

Katzenstein, P. J. and Okawara, N. (1993) 'Japan's national security: structures, norms, and policies', International Security 17(4): 84-118.

Keck, M. E. and Sikkink, K. (1998) Activists Beyond Borders: Advocacy Networks in International Politics, Ithaca: Cornell University Press.

Kennedy, P. (1994) 'Japan: A twenty-first-century power?', in C. C. Garby and M. Brown Bullock (eds) Japan: A New Kind of Superpower?, Baltimore: John Hopkins University Press, pp. 193-9.

Klien, S. (2002) Rethinking Japan's Identity and International Role: An Intercultural Perspective, London: Routledge.

Kosterman, R. and Feshbach, S. (1989) 'Toward a measure of patriotic and nationalistic attitudes', Political Psychology 10(2): 257-74.

Kowert, P. A. (1998) 'National identity: inside and out', Security Studies 8(2-3): $1-34$.

Kowert, P. and Legro, J. (1996) 'Norms, identity, and their limits: a theoretical reprise', in P. J. Katzenstein (ed.) The Culture of National Security: Norms and Identity in World Politics, New York: Columbia University Press, pp. 451-97.

Laclau, E. and Mouffe, C. (1985) Hegemony and Socialist Strategy: Towards a Radical Democratic Politics, London: Verso.

Layne, C. (1993) 'The unipolar illusion: why new great powers will rise', International Security 17(4): 5-51.

Lebow, R. N. (2008) 'Identity and international relations', International Relations 22(4): 473-92.

Littlewood, I. (1996) The Idea of Japan: Western Images, Western Myths, Chicago: Ivan R. Dee. 
Lupovici, A. (2012) 'Ontological dissonance, clashing identities, and Israel's unilateral steps towards the Palestinians', Review of International Studies 38(4): 809-33.

Maull, H. W. (1990/91) 'Germany and Japan: the new civilian powers', Foreign Affairs 69(5): 91-106.

Mearsheimer, J. J. (2001) The Tragedy of Great Power Politics, New York: W. W. Norton.

Mercer, J. (2010) 'Emotional beliefs', International Organization 64(1): 1-31.

Moravcsik, A. (1997) 'Taking preferences seriously: a liberal theory of international politics', International Organization 51(4): 513-53.

Morris-Suzuki, T. (1998) Re-inventing Japan: Time, Space, Nation, Armonk: M.E. Sharpe.

Murray, M. (2010) 'Identity, insecurity, and great power politics: the tragedy of German naval ambition before the First World War', Security Studies 19(4): 656-88.

Neumann, I. B. (1996) 'Self and other in international relations', European Journal of International Relations 2(2): 139-74.

Neumann, I. B. (2003) Mening Materialitet Makt [Meaning, Materiality, Power], Lund: Studentlitteratur.

Oe, K. (1995) Japan, the Ambiguous, and Myself: The Nobel Prize Speech and Other Lectures, Tokyo: Kodansha.

Oguma, E. (2002) A Genealogy of 'Japanese' Self-Images, Melbourne: Trans Pacific Press.

Oros, A. L. (2008) Normalizing Japan: Politics, Identity and the Evolution of Security Practice, Stanford: Stanford University Press.

Pharr, S. J. (1993) 'Japan's defensive foreign policy and the politics of burdensharing', in G.L. Curtis (ed) Japan's Foreign Policy After the Cold War: Coping with Change, Armonk: M. E. Sharpe, pp. 235-62.

Phillips, N. and Hardy, C. (2002) Discourse Analysis: Investigating Processes of Social Construction. New Delhi: SAGE.

Ringmar, E. (1996) Identity, Interest and Action: A Cultural Explanation of Sweden's Intervention in the Thirty Years War, Cambridge: Cambridge University Press.

Ringmar, E. (2012) 'Introduction: the international politics of recognition', in T. Lindemann and E. Ringmar (eds) The International Politics of Recognition, Boulder: Paradigm, pp. 3-23.

Rosecrance, R. (1986) The Rise of the Trading State: Commerce and Conquest in the Modern World, New York: Basic Books.

Rozman, G. (2012) 'Introduction', in G. Rozman (ed) East Asian National Identities: Common Roots and Chinese Exceptionalism, Stanford: Stanford University Press, pp. 1-16.

Rumelili, B. (2004) 'Constructing identity and relating to difference: understanding the EU's mode of differentiation', Review of International Studies 30(1): 27-47.

Saurette, P. (2006) 'You dissin me? Humiliation and post 9/11 global politics', Review of International Studies 32(3): 495-522.

Schulze, K. (2013) 'Facing the 'rise of China': changes in Japan's foreign policy identity', unpublished Ph.D. Thesis, Department for Social Sciences/Institute of East Asian Studies, Duisburg: Duisburg-Essen University.

Singh, B. (2008) 'Japan's security policy: from a peace state to an international state', The Pacific Review 21(3): 303-25.

Soeya, Y (2005) Nihon no 'midoru pawā' gaikō [Japan's Middle Power Diplomacy], Tokyo: Chikuma Shobō. 
Steele, B. J. (2008) Ontological Security in International Relations: Self-Identity and the IR State, London: Routledge.

Suzuki, S. (2005) 'Japan's socialization into Janus-faced European international society', European Journal of International Relations 11(1): 137-64.

Suzuki, S. (2007) 'The importance of "othering" in China's national identity: SinoJapanese relations as a stage of identity conflicts', The Pacific Review 20(1): $23-47$.

Suzuki, S. (2009) Civilization and Empire: China and Japan's Encounter with European International Society, London: Routledge.

Tamaki, T. (2010) Deconstructing Japan's Image of South Korea: Identity in Foreign Policy, Basingstoke: Palgrave Macmillan.

Tanaka, S. (1993) Japan's Orient: Rendering Pasts into History, Berkeley, Los Angeles and London: University of California Press.

Wæver, O. (2002) 'Identity, communities and foreign policy: discourse analysis as foreign policy theory', in L. Hansen and O. Wæver (eds) European Integration and National Identity: The Challenge of the Nordic States, London: Routledge, pp. 20-49.

Waltz, K. N. (1979) Theory of International Politics, New York: McGraw-Hill.

Waltz, K. N. (1993) 'The emerging structure of international politics', International Security 18(2): 44-79.

Waltz, K. N. (2000) 'Structural realism after the cold war'. International Security 25 (1): $5-41$.

Weber, C. (2010) International Relations Theory: A Critical Introduction, London: Routledge.

Weldes, J., Laffey, M., Gusterson, H. and Duvall, R. (1999) 'Introduction: constructing insecurity', in J. Weldes, M. Laffey, H. Gusterson and R. Duvall (eds) Cultures of Insecurity: States, Communities, and the Production of Danger, Minneapolis: University of Minnesota Press, pp. 1-33.

Wendt, A. (1999) Social Theory of International Politics, Cambridge: Cambridge University Press.

Wight, C. (1999) 'They shoot dead horses don't they? Locating agency in the agentstructure problematique', European Journal of International Relations 5(1): $109-42$.

Wight, C. (2000) 'Interpretation all the way down: a reply to Roxanne Lynn Doty', European Journal of International Relations 6(3): 423-30.

Williams, M. C. (1998) 'Identity and the politics of security', European Journal of International Relations 4(2): 204-25.

Wodak, R., de Cillia, R., Reisigl, M. and Liebhart, K. (2009) [1999] The Discursive Construction of National Identity, 2nd edn, Edinburgh: Edinburgh University Press.

Yoshino, K. (1992) Cultural Nationalism in Contemporary Japan, London: Routledge. 